HortSCIENCE 26(2):177-180. 1991.

\title{
Interrelations of Ammonium Toxicity and Ethylene Action in Tomato
}

\author{
Allen V. Barker and Kenneth A. Corey \\ Department of Plant and Soil Sciences, University of Massachusetts, \\ Amherst, MA 01003
}

Additional index words. Lycopersicon esculentum, ethylene inhibitors

\begin{abstract}
Inhibitors of ethylene synthesis and action were used to alleviate ammonium toxicity in tomato (Lycopersicon esculentum Mill. 'Heinz 1350') grown on ammoniumbased nutrient solutions. Aminooxyacetic acid and $\mathrm{Ag}^{+}$were effective in reducing ammonium toxicity, whereas $\mathrm{Co}^{+2}$ and salicylic acid were not. A hypothesis was developed to integrate ammonium accumulation and ethylene biosynthesis into a mechanism for expression of plant injury from environmental stresses.
\end{abstract}

Plants subjected to environmental stresses often develop similar symptoms, regardless of the source of stress (Jacobson and Hill, 1970; Treshow, 1970). Common expressions of plant responses to environmental stresses are leaf chlorosis, necrosis, epinasty, and other foliar malformations (Barker et al., 1989; Barker and Ready, 1989; Bradford and Dilley, 1978; Corey et al., 1987;

Received for publication 16 Jan. 1990. The cost of publishing this paper was defrayed in part by the payment of page charges. Under postal regulations, this paper therefore must be hereby marked advertisement solely to indicate this fact.
Cox and Seeley, 1980; Grannett, 1982 Howe and Woltz, 1982; Staby et al., 1980). The similarities in symptoms often make it difficult to identify and monitor specific factors causing injury because common physiological or metabolic disorders in plants are induced by various environmental stresses (Ormrod and Adedipe, 1975; Reinert, 1975). An acceleration in ethylene evolution follows or coincides with the development of symptoms of environmental stress (Abeles, 1973). The measurement of ethylene production by stressed plants has been proposed as a bioassay for assessing a variety of stresses, such as air pollution, metal toxicity, 
Table 1. Appearance and ethylene evolution by tomato plants grown on nitrate nutrition or on ammonium nutrition with inhibitors of ethylene evolution.

\begin{tabular}{llc}
\hline \hline Treatment & \multicolumn{1}{c}{$\begin{array}{c}\text { Plant } \\
\text { appearance }\end{array}$} & $\begin{array}{c}\text { Ethylene evolution } \\
\left(\mathrm{nl}^{2} \cdot \mathrm{g}^{-1} \cdot \mathrm{hr}^{-1}\right)\end{array}$ \\
\hline $\mathrm{NH}_{4}^{+}$ & $\mathrm{NH}_{4}^{+}$toxic & $49 \mathrm{a}$ \\
$\mathrm{NH}_{4}^{+}, 100 \mu \mathrm{M}$ & & \\
$\quad$ salicyclic acid & $\mathrm{NH}_{4}^{+}$toxic, scorched & $41 \mathrm{ab}$ \\
$\mathrm{NH}_{4}^{+}, 10 \mu \mathrm{M} \mathrm{Ni}^{+2}$ & $\mathrm{NH}_{4}^{+}$toxic & $37 \mathrm{ab}$ \\
$\mathrm{NH}_{4}^{+}, 1 \mu \mathrm{M} \mathrm{Ag} \mathrm{Ag}^{+}$ & Normal & $20 \mathrm{~b}$ \\
$\mathrm{NO}_{-}^{-}$ & Normal & $26 \mathrm{ab}$ \\
\hline
\end{tabular}

${ }^{2}$ Mean separation by Duncan's multiple range test, $P \leq 0.05$.

${ }^{y}$ Symptoms of $\mathrm{NH}_{4}^{+}$toxicity were chlorosis, epinasty, and stunting.

Table 2. Effects of cobalt and aminooxyacetic acid (AOA) on ethylene evolution by plants grown on ammonium nutrition.

\begin{tabular}{llr}
\hline \hline $\mathrm{NH}_{3}^{-}$ & Normal & $23 \pm 2$ \\
$\mathrm{NH}_{4}^{+}$ & $\mathrm{NH}_{4}^{+}$toxic & $42 \pm 5$ \\
$\mathrm{NH}_{4}^{+}, 10 \mu \mathrm{M} \mathrm{Co}^{+2}$ & $\mathrm{NH}_{4}^{+}$toxic & $56 \pm 32$ \\
$\mathrm{NH}_{4}^{+}, 100 \mu \mathrm{M} \mathrm{Co}^{+2}$ & $\mathrm{NH}_{4}^{+}$toxic & $77 \pm 73$ \\
$\mathrm{NH}_{4}^{+}, 1000 \mu \mathrm{M} \mathrm{Co}+2$ & $\mathrm{NH}_{4}^{+}$and Co toxic & $64 \pm 29$ \\
$\mathrm{NH}_{4}^{+}, 1 \mu \mathrm{M} \mathrm{AOA}$ & $\mathrm{NH}_{4}^{+}$toxic & $30 \pm 38$ \\
$\mathrm{NH}_{4}^{+}, 10 \mu \mathrm{M} \mathrm{AOA}$ & Green, stunted & $8 \pm 7$ \\
$\mathrm{NH}_{4}^{+}, 100 \mu \mathrm{M} \mathrm{AOA}$ & Dead & $\mathrm{n} / \mathrm{a}$ \\
\hline
\end{tabular}

'Symptoms of $\mathrm{NH}_{4}^{+}$toxicity were chlorosis, epinasty, and stunting. Symptoms of Co toxicity were chlorosis and necrotic flecking of terminal leaves.

Mean \pm SD.

Table 3. Effects of $1 \mu \mathrm{M} \mathrm{Ag}$ and $10 \mu \mathrm{m}$ aminooxyacetic acid (AOA) on growth, ethylene evolution, and ammonium accumulation in tomato subjected to nitrate or ammonium nutrition.

\begin{tabular}{|c|c|c|c|c|c|}
\hline \multirow[b]{3}{*}{ Treatment } & \multicolumn{5}{|c|}{ Observation ${ }^{2}$} \\
\hline & \multirow[b]{2}{*}{ Appearance $^{y}$} & \multicolumn{2}{|c|}{ Fresh wt } & \multicolumn{2}{|c|}{ Constituent } \\
\hline & & (g/plant $)$ & Roots & $\begin{array}{c}\text { Ethylene } \\
\left(\mathrm{nl} \cdot \mathrm{g}^{-1} \cdot \mathrm{hr}^{-1}\right)\end{array}$ & $\begin{array}{c}\text { Ammonium } \\
\text { (mg N/g) }\end{array}$ \\
\hline $\mathrm{NO}_{3}^{-}$ & 0 & $91 \mathrm{~d}$ & $32 \mathrm{~b}$ & $3.4 \mathrm{a}$ & $0.04 \mathrm{a}$ \\
\hline $\mathrm{NO}_{3}^{-}+\mathrm{Ag}^{+}$ & 0 & $27 \mathrm{a}$ & $11 a$ & $5.8 \mathrm{a}$ & 0.05 a \\
\hline $\mathrm{NO}_{3}^{-}+\mathrm{AOA}$ & 0 & $35 \mathrm{bc}$ & $14 \mathrm{a}$ & $4.5 \mathrm{a}$ & $0.06 \mathrm{a}$ \\
\hline $\mathrm{NH}_{4}^{+}$ & 2 & $39 c$ & $13 \mathrm{a}$ & $18.1 \mathrm{~b}$ & $0.50 \mathrm{c}$ \\
\hline $\mathrm{NH}_{4}^{+}+\mathrm{Ag}^{+}$ & 0 & 28 a & 12. $\mathrm{a}$ & $6.0 \mathrm{a}$ & $0.24 \mathrm{~b}$ \\
\hline $\mathrm{NH}_{4}^{+}+\mathrm{AOA}$ & 1 & $32 \mathrm{ab}$ & $10 \mathrm{a}$ & $18.7 \mathrm{~b}$ & $0.20 \mathrm{~b}$ \\
\hline
\end{tabular}

${ }^{2}$ Mean separation within columns by Duncan's multiple range test, $P \leq 0.05$.

Visual rating of foliage: $0=$ no ammonium toxicity, $1=$ incipient ammonium toxicity, $2=$ ammonium toxicity symptoms strongly expressed

${ }^{x}$ Fresh-weight basis.

pathogenesis, and herbicide injury (Tingey, 1980). Also, ammonium accumulation in leaves frequently accompanies the appearance of symptoms of biotic and abiotic stresses (Lazcano-Ferrat and Lovatt, 1988; Lovrekovich et al., 1970; Puritch and Barker, 1967).

We propose that ammonium accumulation, ethylene evolution, and the appearance of symptoms of environmental stress are interconnected events. Environmental stress may induce hydrolysis of proteins and lead to accumulation of ammonium in tissues. Possibly, ammonium toxicity stimulates ethylene biosynthesis or, conversely, ethylene biosynthesis may stimulate ammonium accumulation, and -these events then initiate development of symptoms. According to this reasoning, factors or agents that detoxify ammonium or that prevent ethylene formation or its action should prevent ammonium toxicity in plants.

We evaluated the effects of inhibiting the synthesis or action of ethylene on plant growth and development by growing 'Heinz 1350' tomato on ammonium nutrition in solution into 1.5-liter, opaque, polyethylene vessels and grown on nitrate-based nutrient solution (Hoagland's No. 1) for 2 weeks. On 13 June 1988, the plants were started on ammonium treatments with $\mu \mathrm{M}$ silver nitrate, $10 \mu \mathrm{M}$ nickel chloride, or $100 \mu \mathrm{m}$ salicylic acid and with ammonium or nitrate nutrition without chemical additives. Plants received these treatments for 12 days. Silver improved plant growth on ammonium nutrition and restricted ethylene evolution (Table 1). These plants were equal in size and vigor to those receiving nitrate nutrition. Plants receiving nickel were not distinguishable in appearance or in rates of ethylene evolution from those receiving ammonium nutrition alone. Treatment of plants with salicylic acid caused scorching of all foliage and did not restrict ethylene evolution or the development of ammonium toxicity symptoms relative to the ammonium-grown plants.

Ethylene synthesis (Expt. 2). Tomato plants, 4 weeks old from seeding, were grown for 2 weeks on nitrate-based nutrient solution, as described for Expt. 1. On 28 June 1988, inhibitors of ethylene synthesis $\left(\mathrm{CoCl}_{2}, \mathrm{AOA}\right)$ were added at variable concentrations to the complete, ammonium-based nutrient solution (Table 2). Plants received these treatments for 8 days. This short treatment period was mandated by the rapid development of ammonium toxicity symptoms and by the necessity of measuring ethylene evolution before the ammonium-grown plants died. Cobalt had no effect in alleviating ammonium toxicity and was phytotoxic at 1000 $\mu \mathrm{M}$. Cobalt also was ineffective in inhibiting ethylene evolution by ammonium-grown plants. However, $10 \mu \mathrm{M} \mathrm{AOA}$ improved the appearance of ammonium-grown plants. Ethylene evolution by plants grown with 10 $\mu \mathrm{M}$ AOA was inhibited relative to that of ammonium-grown plants and was of the same magnitude as or lower than that of nitrategrown plants. At $1 \mu \mathrm{M}$, AOA was ineffective in alleviating ammonium toxicity and apparently did not inhibit ethylene evolution, although the replicates varied widely in ethylene evolution. Within 6 days, $100 \mu \mathrm{M} \mathrm{AOA}$ killed the plants.

Cation interactions (Expt. 3). Tomato plants, 5 weeks old from seeding, were grown on nitrate-based nutrient solution for 2 weeks, as described for Expt. 1. Treatments then were applied on 26 July 1988 as follows: ammonium nutrition in a complete modified Hoagland's solution; ammonium nutrition in a K-deficient modified Hoagland's solution; nitrate nutrition (Hoagland's No. 1); and each of the preceding three solutions with silver nitrate at an initial concentration of $\mathrm{O}$ or 1 $\mu \mathrm{M}$.

Plants were grown on these solutions for 8 days. Plants grown on ammonium nutrition with or without $\mathrm{K}^{+}$were chlorotic and epinastic. Plants grown with the ammoniumbased solutions with $\mathrm{Ag}^{+}$had no symptoms of ammonium toxicity and appeared normal in color, compared to the plants receiving nitrate nutrition. The $\mathrm{Ag}^{+}$had no apparent toxic effects on the nitrate-grown plants. Ethylene evolution varied with source of $\mathrm{N}$ 


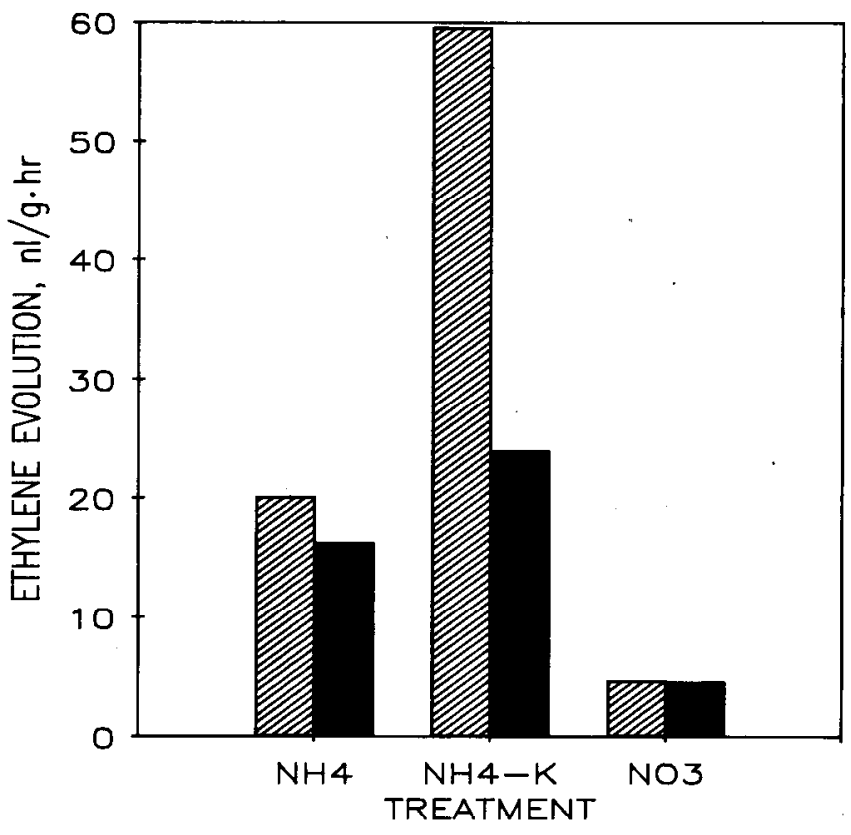

Fig. 1. Ethylene evolution by tomato plants grown on ammonium nutrition, on ammonium nutrition without potassium in the nutrient solution, on nitrate nutrition, and with each nutritional regime having an initial application of $\mathrm{Ag}^{+}$at $0(\square)$ or $1 \mu \mathrm{M}(\mathbf{\square})$.

and with adequacy of $\mathrm{K}^{+}$, but $\mathrm{Ag}^{+}$had no effect on ethylene evolution, except in the K-deficient treatment (Fig. 1).

In the ammonium-based solution; in which $\mathrm{K}$ and $\mathrm{Ca}$ were provided as $\mathrm{Cl}^{-}$salts, $\mathrm{Cl}^{-}$ precipitation reduced $\mathrm{Ag}^{+}$concentration to a potential $0.01 \mu \mathrm{M}$. This precipitation occurred in Expts. 1 and 3. We noted in preliminary studies that even with the reduction in concentration of $\mathrm{Ag}^{+}$by precipitation, sufficient $\mathrm{Ag}^{+}$remained in solution to alleviate ammonium toxicity. Also, in the same preliminary studies, we noted that adding $\mathrm{Ag}^{+}$ at $10 \mu \mathrm{M}$ to nitrate-based solutions caused virtually immediate wilting of the plants. This action was readily reversible with the addition of $\mathrm{Cl}$ - to lower the concentration of $\mathrm{Ag}^{+}$ to $0.01 \mu \mathrm{M}$.

Nitrogen source and inhibitors (Expt. 4). Tomato plants, 6 weeks old from seeding, were grown on nitrate-based nutrient solution for 1 week, as described in Expt. 1. Treatments were applied to provide nitrate and ammonium nutrition with $\mathrm{Ag}^{+}$or $\mathrm{AOA}$ added at 1 or $10 \mu \mathrm{M}$, respectively. After 8 days of treatment (22-30 May 1989), plants showed an array of responses to the treatments (Table 3). Plants receiving nitrate nutrition alone were larger than those in the other treatments. Plants receiving ammonium nutrition alone showed foliar symptoms of ammonium toxicity. Plants receiving $\mathrm{Ag}^{+}$and ammonium nutrition had no ammonium toxicity symptoms, whereas plants receiving $\mathrm{AOA}$ and ammonium nutrition had some mottling of foliage, an apparent toxic response to the ammonium. Each of the inhibitors restricted plant growth relative to that occurring in their absence.

For determinations of ethylene and ammonium, portions of shoots were excised from the tip to include the first two fully expanded leaves. These shoot portions were sealed in 500-ml vessels (l-pint Mason jars) that were fitted with rubber septa. Ethylene accumulation in the vessels was measured after $2 \mathrm{~h}$ [Corey et al., 1987). The excised shoots were extracted by grinding in a solution of $1 \mathrm{M}$ $\mathrm{KCl}$ and $0.02 \mathrm{M} \mathrm{CuSO}_{4}$ and washing by vacuum filtration. Ammonium-N was determined by steam distillation (Barker and Volk, 1964). Plants grown on ammonium nutrition with no inhibitors accumulated more than 10 times as much ammonium- $\mathrm{N}$ as those grown on nitrate nutrition. Plants receiving ammonium nutrition with the inhibitors present accumulated less than half the ammonium$\mathrm{N}$ of those on ammonium nutrition alone, but 4-fold or 5-fold more than that in the nitrategrown plants (Table 3 ). These accumulations of ammonium-N were in phytotoxic ranges (Barker et al., 1966b; Maynard and Barker, 1969). Silver inhibited the production of ethylene by ammonium-grown plants (Table 3 ). This result is probably due to the effect of $\mathrm{Ag}^{+}$in inhibiting the action of ethylene and inhibiting the autocatalytic effect of ethylene on ethylene biosynthesis (Yang, 1985). The effects of AOA are not clear. Apparently, toxicity was incipient in the ammonium-grown plants receiving AOA, as manifested by their slight chlorosis, moderate ammonium accumulation, and high ethylene evolution.

Environmental stress, such as that induced by ammonium toxicity, promotes ammonium accumulation and ethylene evolution (Corey and Barker, 1989; Maynard and Barker, 1969; Puritch and Barker, 1967). If either of these phenomena is prevented, plant growth may be normal. In the present study, chemical inhibition of ethylene synthesis or action prevented expression of ammonium toxicity symptoms on plants receiving all of their $\mathrm{N}$ from $\mathrm{NH}_{4}^{+}$salts.

For plants receiving ammonium nutrition, the inhibitors were consistently effective in

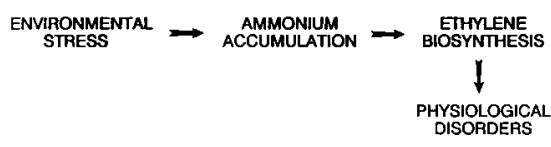

Fig. 2. Proposed mechanisms for expression of physiological disorders initiated by environmental stress and mediated by ammonium accumulation and ethylene biosynthesis.

restricting ammonium accumulation but not in limiting ethylene evolution. Although ethylene production was not restricted in the $\mathrm{Ag}^{+}$-treated plants in one experiment, ammonium toxicity symptoms were not expressed. In another experiment, AOA limited ammonium accumulation but did not inhibit ethylene evolution relative to the control on ammonium nutrition. The AOA-treated plants in this case had incipient ammonium toxicity symptoms. Perhaps, $\mathrm{Ag}^{+}$or $\mathrm{AOA}$ were not maintained at sufficient levels in the plants to be effective inhibitors. Cobalt and salicylic acid were ineffective in restricting ethylene evolution or in improving plant appearance. Toxicity symptoms induced by $\mathrm{Co}^{+2}$ or salicylic acid indicated that these agents were entering the plant; however, they were ineffective in restricting ethylene synthesis or reducing ammonium toxicity.

Ethylene evolution by environmentally stressed plants appears to be a universal characteristic (Tingey, 1980), and ammonium accumulation in stressed plants is a common occurrence (Lazcano-Ferrat and Lovatt, 1988; Lovrekovich et al., 1970; Puritch and Barker, 1967). Ammonium nutrition of plants induces ethylene evolution solution and ammonium accumulation. Because of the predominance of cation absorption from ammonium-based nutrient solutions, the growth medium becomes strongly acidified, reaching a pH as low as 2.8 (Maynard and Barker, 1969). Buffering of growth media against acidification prevents ammonium accumulation in shoots, the resulting ammonium toxicity, and the evolution of stress ethylene by ammonium-grown plants (Barker et al., 1966a, 1966b; Corey and Barker, 1989; Maynard and Barker, 1969). These responses suggest that ammonium accumulation, ethylene synthesis, and plant injury from stresses are correlated events. A hypothesis of an interrelationship among environmental stress, ammonium accumulation, ethylene evolution, and expression of stress symptoms is proposed (Fig. 2). Accordingly, environmental stress brings about an accumulation of ammonium in cells; this event then initiates or stimulates ethylene biosynthesis, which brings about the development of toxicity symptoms. Accumulation of ammonium in cells may alter protein structure and subject the proteins to catabolism (Barker, 1968). In plants expressing symptoms of ammonium toxicity, $60 \%$ of the accumulating ammonium under this stress is derived from internal sources and only $40 \%$ from the external solution (Barker et al., 1966a). It is possible that ethylene biosynthesis precedes ammonium accumulation. Also, other events may stimulate ethylene 
biosynthesis without the participation of ammonium. For example, ripening tomato fruits evolve ethylene without an accompanying accumulation of ammonium (Barker, 1990). However, the frequency of ammonium accumulation reported in stressed plants strongly suggests that ammonium accumulation is a, common denominator in the initiation of ethylene biosynthesis and the expression of injury symptoms.

\section{Literature Cited}

Abeles, F.B. -1973. Ethylene in plant biology. Academic, New York.

Barker, A.V. 1968. Ammonium interactions with proteins. Biochim. Biophys. Acta 168:447-455.

Barker, A.V. 1990. Ethylene evolution by fruits of tomato stressed by ammonium nutrition. HortScience 25:625.

Barker, A.V., K.A. Corey, and L.E. Craker. 1989. Nutritional stresses in tomato genotypes grown under high-pressure sodium vapor lamps. HortScience 24:255-258.

Barker, A.V. and K.M. Ready. 1989. Growth and composition of tomato as affected by source of nitrogen and biocides. J. Plant Nutr. 1295-109.

Barker, A.V. and R.J. Volk. 1964. Determination of ammonium, amide, amino, and nitrate nitrogen in plant extracts by a modified Kjeldahl method. Anal. Chem. 36:439-441.

Barker, A.V., R.J. Volk, and W.A. Jackson. 1966a. Root environment acidity as a regulatory factor in ammonium assimilation by the bean plant. Plant Physiol. 41:1193-1199.

Barker, A.V., R.J. Volk, and W.A. Jackson. 1966b. Growth and nitrogen distribution patterns in bean plants (Phaseolus vulgaris L.) subjected to ammonium nutrition: I. Effects of carbonates and acidity control. Soil Sci. Soc. Amer. Proc. 30:228-232.

Beyer, E.B., Jr. 1976. A potent inhibitor of ethylene action in plants. Plant Physiol. 58:268271.

Bradford, K.J. and D.R. Dilley. 1978. Effects of root anaerobiosis on ethylene production, epinasty, and growth of tomato plants. Plant Physiol. 61:506-509.

Corey, K.A. and A.V. Barker. 1989. Ethylene and polyamine accumulation by tomato subjected to interactive nutritional stresses of ammonium toxicity and potassium deficiency. J. Amer. Soc. Hort. Sci. 114:651-655.

Corey, K.A., A.V. Barker, and L.E. Craker. 1987. Ethylene evolution by tomato plants under stress of ammonium toxicity. HortScience 22:471-473.

Cox, D.A. and J.G. Seeley. 1980. Magnesium nutrition of poinsettia. HortScience 15:822-823.

Hoagland, D.R. and D.I. Amen. 1950. The water culture method for growing plants without soil. California Agr. Expt. Sta. Circ. 347.

Howe, T.K. and S.S. Woltz. 1982. Sensitivity of tomato cultivars to sulfur dioxide. HortScience 17:249-250.

Granett, A.L. 1982. Pictorial keys to evaluate foliar injury caused by hydrogen fluoride. HortScience 17:587-588.

Jacobson, J.S. and A.C. Hill (eds.). 1970. Recognition of air pollution injury to vegetation: A pictorial atlas. Air Pollution Control Assn., Pittsburgh.

Lau, O. and S.F. Yang. 1976. Inhibition of ethylene production by cobaltous ion. Plant Physiol. 58:114-117.

Lazcano-Ferrat, L and C.J. Lovatt. 1988. Salt stress results in ammonia intoxification of Phaseolus spp. HortScience 23:720.

Leslie, C.A. and R.J. Romani. 1986. Salicylic acid: A new inhibitor of ethylene biosynthesis. Plant Cell Rpt. 5:144-146.

Lovrekovich, L., H. Lovrekovich, and R.N. Goodman. 1970. Ammonia as a necrotoxin in the hypersensitive reaction caused by bacteria in tobacco leaves. Can. J. Bot. 48:167-171.

Maynard, D.N. and A.V. Barker. 1969. Studies on the tolerance of plants to ammonium nutrition. J. Amer. Soc. Hort. Sci. 94:235-239.

Ormrod, D.P. and N.O. Adedipe. 1975. Experimental exposures and crop monitors to confirm air pollution. HortScience 10:493-494.

Puritch, G.S. and A.V. Barker. 1967. Structure and function of tomato leaf chloroplasts during ammonium toxicity. Plant Physiol. 42:12291238.

Reinert, R.A. 1975. Monitoring, detecting, and effects of air pollutants on horticultural crops: Sensitivity of genera and species. HortScience 10:495-500.

Staby, G.L., B.A. Eisenberg, J.W. Kelley, M.P. Bridgen, and M.S. Cunningham. 1980. Leaf petiole epinasty in poinsettias. HortScience 15:635-636.

Tingey, D.T. 1980. Stress ethylene productionA measure of plant response to stress. HortScience 15:630-633.

Treshow, M. 1970. Environment and plant response. McGraw-Hill, New York.

Yang, S.F. 1985. Biosynthesis and action of ethylene. HortScience 20:41-45. 